AJIT-e: Online Academic Journal of Information Technology

2019 Bahar/Spring - Cilt/Vol: 10 - Sayı/Num: 37

DOI: 10.5824/1309-1581.2019.2.001.x

http://www.ajit-e.org/?menu=pages\&p=details_of_article\&id=421

Received: 22.04.2019

Editorial Process Begin: 02.05.2019

Published: 15.06 .2019

\title{
Dijitalleşen Zamanın İzdüşümünde: Kimliğin, Bedenin ve İletişimin Dönüşümü
}

\author{
Ahmet ÇifTçi, Ankara Hacı Bayram Veli Üniversitesi, Iletişim Fakültesi Radyo TV Sinema Bölümü, Prof. Dr., \\ aciftci@gazi.edu.tr \\ Yelda KARAKAŞ, Gümüşhane Üniversitesi, Iletişim Fakültesi Radyo Televizyon Bölümü, Arş.Gör., \\ yelda.karakas@gumushane.edu.tr https://orcid.org/0000-0003-1528-6286
}

ÖZ Dijitalleşme, modern bireyin ve gündelik yaşamın büyük oranda, diyalektik unsurlarını potasında eritmektedir. Geleneksel toplumlardan modern toplumlara geçişin beraberinde getirdiği Bauman'ın ifadesiyle "akışkanlık ve müphemlik", dijitalleşmenin de etkisiyle geleneŏin katı ve yerleşik formlarını yerinden etmiştir. Örneğin ontolojik zaman kavramı yerini Castells'in deyimiyle "zamansız zaman" kavramına, yerleşik-somut mekân algısı ise yerini "boyutsuz mekân" veya "siber-mekân" anlayışına bırakmıştır. Bireyin gündelik yaşamında belirleyici bir unsur olan kimlik de bütünlükçü ve tutarlı yapısından soyutlanarak "atomlaşmıştır". Bu değerler artık anlık ve geçici olanın göstergesel temsilleridir. Insan canlılı̆̆ının alamet-i farikası olan beden ise, hem dijitalde konumlanan hem de dijitalin konumlandığı bir boşluğu ya da müphemliği ifade etmektedir. Zaman, mekân, kimlik ve bedende gerçekleşen dönüşümlerle iletişimin de niceliği ve niteliği değişmiş, dönüşmüştür. Gündelik hayatın "burada ve şimdi"ye dayalı gerçekliğinden, hiyerarşisinden ve yüzyüzeliğinden styrulan iletişim, ya doğrudan Baudrillard'ın deyimiyle "hipergerçek" siberuzama taşınmıştır ya da dijital aygıtlar aracılı̆̆ıyla sağlanır. Dijital kültürün, tüm taşınabilir/mobil, sabit ve giyilebilir teknolojileri gündelik yaşamın unsurlarında kendini görünür kılar, bu görünürlük hem somut formasyonlarm yerine getirilmesinde hem de sosyozihinsel aktivitelerde belirgindir. Bu çalışma, artık müstakil değerleri ifade etmeyen zaman, mekân, kimlik, benlik ve iletişim olgularının gündelik hayatın dijitalleşmesiyle uğradıkları dönüşümü ele almaktadır. Enformasyona dayalı ă̆lar gündelik hayatı örgütlü bir sisteme çevirmiş, bireyler, içinde konumlandıkları devasa ă̆da, özne-nesne paradigmasından, nesnenesne paradigmasına doğru, dijitalin seyrinde bir yol kat etmektedir.

Anahtar Kelimeler: Modernite, Kimlik, Beden, Uzam, Zaman, İletişim, Dijitalleşme

\section{In the Projection of Digital Times:}

\section{Transformation of Identity, Body and Communication}

ABSTRACT Digitalization significantly melts the dialectical elements of the everyday life and modern individual. The transition from traditional societies to modern societies brought (in Bauman's sense) "liquidity and ambivalence" about has displaced the solid and established forms of tradition with the effect of digitalization. For example, the concept of ontological time has replaced by the perception "timeless time" with Castellian conceptualisation, and "lostdimension" or "cyber-space" instead of space perception of entrenched and tangible. Identity, which is a determinative factor in the everyday life of the individual, has been atomized by being abstracted from its integral and consistent structure. These values henceforth indicative of the momentary and temporary. The body, which is the sign of human life, refers to a void or 
ambivalance in which both digitally positioned and digital is located. The quantity and quality of communication have changed and transformed by with happening transformations of time, space, identity and body. Communication that is by isolated from hierarchy, face to face and reality of everyday life -which is based here- and now, either directly is moved to (with Baudrillard's phrase) "hyper-real" cyber-space or is provided through digital devices. All of mobile/movable, stationary and wearable technologies of digital culture, it makes itself apparent in the elements of everyday life, this appearance is evident in both the implementation of tangible formations and in socio-mental activities. This study deals with the transformation of time, space, identity, self and communication phenomena no longer that express singular values with the digitalization of everyday life. Information-based networks have turned everyday life into an organized system and individuals who located in the gigantic network have passed from "the subject-object paradigm" to "the object-object paradigm" in the course of digitalization.

Keywords: Modernity, Identity, Body, Space, Time, Communication, Digitalisation

\section{GíRIŞ}

Çağ değişimleri, nesnelerin düzeni ile düşüncenin düzeni arasındaki ontolojik ilişkinin değişmesi veya başkalaşması anlamına gelir. Bu temel ilişki sadece, nesnelerin gerçeklik kazandıkları zaman ve mekân ile insan ilişkisinin değişiminde değil, insanın algı ve hafızasının biçimlenmesinde de önemli rol oynar (Şentürk, 2017, s. 95). Antik Yunan düşüncesinin Aristotelesçi teolojik ontoloji anlayışında toplumun dünyayı, düzeni anlaması ve algılayışı bütünlükçü, hiyerarşik, metafizik ve teolojik bir anlayışa dayanıyordu, bu toplumlarda varlığın ve oluşun gerçekliği bir sorgulama nesnesi olmamakla birlikte, insanın geçici oluşu, zamanın ve mekânın ise sürekliliği, kalıcılığı söz konusuydu. Dünyaya yönelik bu algilayışta Rönesans dönemi ve sonrasında bir dönüşüm ve değişim baş göstermiştir (2017, s. 96-97). On yedinci yüzyılda gerçeklik ve güven, varlığın sorgulanmasında başat nesnelerdi, bundan sonra hâkim görüş, Aristoteles'in ontolojik anlayışı değil, René Descartes'ın eleştirel akla ve bilime dayalı sorgulayıcı, şüpheci görüşüydü. Bu süreçte teoloji ve metafizik anlayış yerinden edilmiş (fakat yok edilememiş), bilim ve teknoloji ise gelişmiş beraberinde Sanayi Çağı ve Endüstri Çağına yol açmıştır. Bundan sonrasıysa enformasyon teknolojilerinin gelişimi ve çağın bu gelişen teknolojiye ayak uydurması olmuştur. Özellikle bilgi iletişim teknolojilerindeki gelişme, beraberinde yeni bir kültürü getirmiş ve toplumsallaştırmıştır. Çağımız, dijital çağ, enformasyon çağı, bilişim çağı, uzay çağı gibi farklı isimlendirmelere tabi tutulmuştur.

Neil Postman teknolojinin hâkim olduğu yeni toplumu "Teknopoli" kavramıla açılar. Teknopoli bir kültür ve akıl ülkesidir. Teknopoli, teknolojinin tanrılaşmasıdır. Kültür hâkimiyeti, teknolojide aramaktadır, doyumu teknolojide bulmaktadır ve teknolojiden emir almaktadır. Bu durum geleneğin çözülmesini gerektirirken, yeni bir toplumsal düzenin gelişmesine ihtiyaç duyar. Teknopoli'de yaşayanlar arasında kendini en konforlu hissedenler ise, teknik ilerlemenin insanlığın en büyük başarısı olduğuna ve teknik ilerlemeyle en büyük ikilemlerimizin çözülebileceğine ikna olmuş olanlardır. Ayrıca bu insanlar, enformasyonun, sürekli ve denetimsiz üretiminin ve yayılmasının daha fazla özgürlük, yaratıcılık ve iç huzuru sağlayacak saf bir lütuf olduğuna inanırlar (Postman, 1993, s. 71). Teknoloji bugün 
gelişmiş ve gelişmekte olan toplumlar için hâkim unsurdur, toplumsal pratiklerde belirleyiciliğe sahiptir ve elbette vazgeçilmez olarak telakki edilen bu unsur doğrudan ve dolaylı olarak kültürü ve toplumları şekillendirir. 1994 yılında Philadelphia Liberty Madalyası'nı aldıktan sonra, Çek Cumhuriyeti Cumhurbaşkanı Vaclav Havel, postmodernizmi, küresel kültürün temel koşulu olarak, bu yeni dünya düzenini de 'çok kültürlü bir çağ' olarak tanımlamıştır. Küresel politika ile postmodern kültür arasında hayati bir bağ olduğu düşünülmektedir (Campbell, Martin, \& Fabos, 2012, s. 32).

Toffler (Toffler, 2008) tarım toplumlarını Birinci Dalga, endüstri toplumlarını İkinci Dalga metaforuyla açıklarken, içinde bulunduğumuz süreci Üçüncü Dalga metaforuyla açıklar, bu süreçte insanlık ileri doğru bir sıçramayla karşı karşıyadır, tüm zamanların en derin sosyal çalkantıları ve yaratıcı yeniden yapılanma süreci gerçekleşmektedir, yeni uygarlığın pek çok yönü geleneksel endüstri toplumunun değerleriyle çatışmaktadır, Üçüncü Dalga yeni bir yaşam tarzını, yeni yapıları, yeni davranış kalıplarını beraberinde getirmektedir. Aslında bu son dönemi tanımlayan ek "ötesi-post" ekidir, endüstri-ötesi, yapısalcılık-ötesi, modern-ötesi gibi eklerin gelmesine zemin hazırlayan ve ana etken olan durum ise bilgi iletişim teknolojilerinin - enformasyon teknolojilerinin gelişmesi ve hayatın akışı içine girmesidir (Alemdar \& Erdoğan, 2005, s. 415). İçinde bulunduğumuz postmodern durum-dönem-çağ insanın, nesneler sistemi, mekân, zaman, hız, gerçeklik, beden, iletişim ve daha niceleriyle ilişkisinin enformasyon teknolojileri aracılığıyla radikal bir dönüşüme uğradığı zaman dilimidir.

Bugün beşerî olana dair pek çok şey dijitalin beşiğindedir. Dijitalleşme, insan varoluşunun ve gündelik hayatının tüm diyalektik unsurlarını potasında eritmektedir. Artık zaman, mekân, kimlik, benlik, iletişim, tüketim, üretim süreçleri ve olguları müstakil değerler değildir ve dijitalleşmeyle yeniden inşâ edilenlerdir. Tüm taşınabilir, sabit ve giyilebilir teknolojiler gündelik yaşamın unsurlarında kendini görünür kılar, bu görünürlük hem somut formasyonların yerine getirilmesinde hem de sosyo-zihinsel aktivitelerde belirgindir. Enformasyona dayalı ağlar gündelik hayatı örgütlü bir sisteme çevirmiştir. Gündelik hayatın enformasyona dayalı dijitalleşmesini gerek devlet gerek özel sektör kurumlarının işleyişlerinde, ev merkezli çalışma düzeninde, telealışveriş-online tüketici hizmetlerinde, sağlık hizmetlerinde, eğitim-öğretim ve sosyal hizmette, eğlence sektöründe ve gündelik hayatın işleyen mekanizmalarında aktif olarak görmek gittikçe sıradanlaşacaktır.

Dijitali böylesine yaygınlaştıran unsur küreselleşmedir, küreselleşmenin anlamı ise Bauman'ın deyimiyle "dünya meselelerinin belirsiz, ele avuca sığmaz ve kendi başına buyruk doğasıdır; bir merkezin, bir kontrol masasının, bir yönetim kurulunun, bir idari büronun yokluğudur" (Bauman, Küreselleşme Toplumsal Sonuçları, 2010, s. 64). Küreselleşme kimileri için özgürlüğün-sınırsızlığın vazgeçilmez bir unsuru, kimileri içinse devasa bir baskı unsurudur. Küreselleşmeyle yayılan "teknoloji insanlar birbirine bağlamak ve etrafindaki dünyayı etkilemek için giderek daha fazla yol ürettikçe teknolojik olarak tanınan aktiviteler günlük hayata " dönüşmüştür (Chayko, 2018, s. 4), bundan böyle gündelik hayatın dijitalleştiği bir çağı yaşamaktayız, ve bu yadsınamaz toplumsal bir gerçeklik olarak karşımıza çıkmaktadır. 


\section{Yaklaşım ve Yöntem}

$\mathrm{Bu}$ çalışma, modernlik öncesi geleneksel toplumlarda insanın zaman-mekân-kimlik-iletişim ve beden olgularına yönelik algılayışı ile bu unsurların gündelik hayatta edinmiş oldukları veya karşılık geldikleri konumların ve anlamların, modernleşme sonrası dijitalleşme ekseninde nasıl değiştiği ve dönüştüğü üzerine literatür taramasına dayalı olarak gerçekleştirilmiştir.

Çalışmada modernlik, geç-modernlik ve post-modernlik kavramları kullanılmış olmakla beraber, kavramların ihtivâ edildiği kuramsal bir tartışmaya gidilmemiştir. Çalışmanın amacı, kuramsal olarak dönemi kavramsallaştırmak değil, gündelik hayatın dijitalleşen boyutlarının getirmiş olduğu dönüşümü idrâk etmektir.

\section{Kimliğin Dijitalleşmesi}

Kimlik insanın varlığa dair sorgulamasının somut bir kavramıdır, "ben"e dair sorgulamasının sosyal yaşantısındaki tezahürüdür. Kimlik toplumsal bir unsur olarak, bireyin anlam arayışında inşa ettiği ilk yapıdır, anlam çerçevesidir, sosyal ilişkilerin kilididir.

Kimlik yapısı gereği sosyolojide doğuştan sabit ve değişmez biçimde görülmez, aksine tarihsel süreçlerden, toplumsal gerçeklerden etkilenerek şekillenir, sosyo-psikolojik bir temeli vardır, bir oluş halidir, imajdır, süreçler içinde inşâ edilendir.

Aydınlanma öncesinde, bireylerde geleneksel toplumsal kimlik (tartışma unsuru olmaksızın) karşılık bulurken, modernizimle birlikte bu geleneksel kimlik anlayışını temellendiren ögeler aydınlanma-pozitivizm ve rasyonalizm temelinde şekillenmiştir. Bu dönüşümde sabit unsurların yerini başka sabitlere- kesin doğrulara-kesin gerçekliklere bıraktığı görülür. Toplumsal grup bağlarındaki çözülmenin başlangıcı olarak görülen modernizm süreci bireyselleşmeyi ve bireysel kimlikleri öne çıkarır, bireyler modernizmin sunduğu özgürlük ve kendi yaşamını tayin etme hakkı algısıyla kimliğini yapılandırır. Modernitede kimlik bireyin benliğini sunuş şekli, bir özgürlük alanı, kendini gerçekleştirmesi olarak karşımıza çıkmıştır, ne var ki özgürlük ve seçim hakkının çokluğu bireyde anlamsal bir sorunsala, karışıklığa ve iç gerilimlere neden olmuştur bu gerilimli hâl postmodern bireylerde daha görünürdür. Modernitede kimlik sorunu, "bir kimliğin nasıl inşa edileceğ i ve nasıl sağlam tutulacağına dair idiyse, postmodern kimlik sorunu, birincil olarak sabitlemekten nasıl kaçılacă̆ı ve seçeneklerin nasıl açık bırakılacağına dairdir" modernliğin sloganı "yaratım" olurken, postmodernliğin sloganı "yeniden kullanıma sokma" dır (Bauman, 2018, s. 116). Bireyler süreç içerisinde biteviye inşa ettikleri kimliklerini, farklı mekân, zaman ve durumlarda yeniden kullanıma sokarlar.

Friedman'ın (Friedman, 1999), "teknoloji ve bilim dünyayı baş aşağı, tersyüz etmiştir" sözü postmodernitede gündelik hayatın her veçhesinde görünür kılınmıştır. Eski, sıkı ve dikey kimliklerin ve ilişkilerin gevşediği, bireylerin yeni anlam ve bağlantı arayışında olduğu bir dünyada yaşıyoruz. Friedman'ın yatay toplum olarak adlandırdığı günümüz toplumunda kimlikler ilk kez bir sorunsal olarak karşımıza çıkmıştır. Kimlik artık karmaşık ve belirsizdir, yeni dijital kültürde daha fazla bireysellik, daha fazla seçenek, kişisel memnuniyet ve 
kendini gerçekleştirme kültürü vardır. Emily Martin'in (Martin, 1994) ifadesiyle bedenlerin, hükümetlerin, iş dünyasının esnekleştiği ve geçirgenleştiği bir toplumda kimlik ve kültür de esnekleşmiş ve geçirgenleşmiştir.

"Servet, güç, imge akışının küresel olduğu bir dünyada, kolektif ya da bireysel, atfedilmiş ya da inşa edilmiş bir kimlik arayışı, toplumsal anlamın temel kaynağı haline geliyor." (Castells, 2013, s. 3). Castells yeni toplumsal düzende, postmodern toplumda kimlik, benlik ve toplum arasındaki ilişkiyi şöyle izah eder:

\footnotetext{
“İnsanlar giderek anlamlarını ne yaptıkları etrafında değil, ne oldukları ya da olduklarına inandıkları etrafında örgütlüyor... Toplumlarımız giderek A $\breve{g}$ ile benlik arasındaki çift kutuplu bir karşıtlık etrafında yapılanıyor... İşlev ile anlam arasındaki bu yapısal şizofreni durumunda, toplumsal iletişim şablonları da hızla baskı altına giriyor. İletişim kopunca, çatışma ihtiva eden bir iletişim olarak dâhî varlığını sürdüremediğinde toplumsal gruplar ve bireyler birbirine yabancılaşıyor, ötekini bir yabancı, nihayetinde bir tehdit olarak görmeye başlıyor. Bu süreçte kimlikler daha özgül, paylaşması güç hale gelirken toplumsal parçalanma da yayıllyor" (Castells, 2013, s. 4-5)
}

Kimlik bu yeni toplumsal düzende belirleyici bir etmendir, imaja, yapılandırmaya dayalı bir güç unsurudur, olmanın değil sahip olmanın göstergesel temsilidir. Bununla birlikte içinde bulunulan sosyal-ekonomik ve siyasi süreç bireyleri farklı kimlikler edinmeye mecbur bırakmaktadır, şu gerçek göz ardı edilmemelidir ki, bu dönüşümler ve değişimler siyasiekonomik ve bireysel ağlar ile sistemler arasındaki sıkı ilişkinin tezahürüdür.

Kimlik hakkında çeşitli tartışmaların olmasına rağmen genel olarak kimliğin özdeşim ve bireyleşme olarak iki zit yönünün olduğuna dair görüş birliği vardır. Özdeşim, bireyin ötekilerle benzerliğini vurgularken, bireyleşme ötekilerle farklılığı vurgular. Bu iki özellik birbirine zıt görünse de G.H. Mead (Mead, 2017) aslında bunun böyle olmadığını, bireyin toplumsal gruplar içinde biçimlendiğini belirtir, kimlik değil benlik kavramını kullanan Mead, benliği toplumsal deneyimden ayrı tutmaz. Kimliğin esasen iki işlevi vardır biri, ilişkiler sistemi içinde sınırları belirlemek bir diğeri de ilişkiler sistemine bireyi entegre etmektir, yani bir taraftan (ilişkisel-iletişimsel) sürekliliği, bir taraftan da (ilişkiseliletişimsel) süreksizliği oluşturmaktır. Kimliğin bu iki boyutunu Goffman, "sanal toplumsal kimlik" ve " gerçek toplumsal kimlik" olarak tanımlar, bu iki boyut hem bireysel hem de kolektif kimliğin temelinde yer almaktadır (Borlandi, Boudon, Cherkaoui, \& Valade, 2011, s. 412-413).

\section{Sanal Kimlik}

Postmodern süreç öncesinde daha katı ve sabit bir forma sahip olan kimlik postmoderniteyle birlikte kırılgan ve akışkan, belirsiz, sınırsız, sanal bir forma tekabül etmiştir, sanal mecralarda kimliğin oluşu, bir sürece dâhî karşılık gelmez, anlık ve geçicidir.

Goffman'da benlik/kimlik kavramları dramatürjik bir performansı ve enformasyon oyununu ifade eder (Şentürk, 2017, s. 43). Onun için gündelik yaşam bir tiyatro sahnesine benzer, kişilerin rolleri vardır ve burada performanslarını sergilerler, fakat gündelik yaşam sahneye göre daha gerçekçidir, sahne yapmacık şeyler sunarken, gündelik yaşam daha gerçek ve 
prova edilmemiş olanı sunar (Goffman, 2016). Goffman performansı, belli bir durumda belli bir katılımcının diğer katılımcılardan herhangi birini etkilemeye yönelik tüm etkinlikleri olarak açılar (s. 28) kişi rolünü başkalarını etkilemek ve kendisi hakkında olumlu izlenimler bırakmak için yapabilirken, girmiş olduğu rolü benimseyerek, oluşturduğu gerçeklik izlenimine kendisini de inandırabilir. "Kişi (person)" sözcügünün ilk anlamının "maske" olduğu göz önünde bulundurulursa (s. 31), dijital/sanal dünya maskelerin en kalın ve en sık değiştirilebildiği bir mecra olmaya çok uygundur, bu nedenle dijital/sanal dünya bir maskeler diyarıdır. Goffman gibi, Douglas Kellner da bugün kimliğin "serbestçe seçilen bir oyuna, benliğin icra ettiği bir tiyatro temsiline dönüştüğü" kanısındadır, kimlik üzerindeki bu keyfi ve radikal oyunlar ise bireyin kimlik üzerindeki denetimini kaybetmesine yol açabilir, bu durum dâhî müphemliğin bir göstergesidir (bkz:Bauman, 2018, s. 115). Kimlik doğası gereği zaten bir sorun olarak var olmakla birlikte, kişi ancak nereye ait olduğuna dair bir kuşku duyduğunda kimlik üzerine düşünmektedir, kimlik bu "belirsizlikten kaçış arayışına verilen addır" (Bauman, 2018, s. 117). Yine Turkle da gündelik yaşamın ağa bağlı teknolojilerinde, milyonlarca kullanıcının gerçek ve bütüncül bir kimlik fikrini baltalayan çeşitli sanal topluluklarda yaşayan çevrimiçi şahıslar oluşturduklarını, rol yaptıklarını ve sanal cemaatler meydana getirdiklerini ifade eder, bu sanal cemaatler internet çağında insan kimliği üzerine düşünülebilecek anlamlı bir bağlam sunar (Turkle S. , 1997, s. 267-268).

Gündelik yaşamda kişinin performansının, gözlemcilere durumu tanımlamak için genel ve değişmez bir şekilde işleyen kısmını Goffman "vitrin" (Front) kavramıyla açıklar (Goffman, 2016, s. 33). Vitrin nasıl ki gündelik yaşamda zaman, mekân ve seyircilere göre değişebiliyorsa, sanal mecrada da kimlikler/benlikler üzerinden kişinin vitrini sürekli değişime uğrayabilir. Goffman'ın kişisel vitrin parçaları olarak saymış olduğu, cinsiyet, yaş, ırk, boy, görünüş, duruş şekli, jest ve mimikler gibi özelliklerden bazıları (ırksal özellikler gibi) sabittir, bazıları ise (jest-mimik vb.) değişkendir, sanal mecralarda biz bu kişisel vitrinin her parçasının yeniden inşa edilebileceğini ya da direk kimliğin ve dolayısıyla vitrinin yok edilebileceğini rahatlıkla söyleyebiliriz.

Dijitalleşmiş, çok parçalı, değişken kimlikler bireylerin kişisel vitrinleridir, performansın gerçek hayatta devam etmesi muhtemel değilse, yani kurulan ilişkiler anlıksa, gerçek ilişkilerden ve bireylerden bahsetmiyorsak, sabit bir vitrinden de söz edemeyiz, vitrin sanal mecralarda kişinin performansını sahnelemesi için, göstergeler düzeyindeki ilk aşamadır, sanal kimliklerin sunum alanıdır. Gündelik yaşamda benliğin sunumunda nasıl ki birey kendini idealize ediyorsa, sanal mecrada ve/veya sanal kimliklerle de aynı işleyişi devam ettirir, kirli işlere ait ya da olumsuzlanan davranışlara dair kanıtlar varsa, bunlar gizlenir, istenilen özellikler ise öne çıkarılır. Modern zamanda benlik/kimlik sunumu hem gündelik hayatta hem de bunun bir uzantısı olarak dijital hayatta ya da gündelikten tamamen bağımsız olarak sanal dünyada kutsallaştırılır. Dijital/sanal evren, kişilerin idealize edilmiş, kutsallaştırılmış durumların performansının sunulduğu mecradır, burası sanal mecrada da gündelik yaşamdaki ilişkilerini devam ettiren gerçek bireyler için gündelik hayattaki performansın devamı olarak görülebilecekken, sanal kimlikler için idealize edilmiş sayısız kimliğin sunulduğu mecradır. Dolayısıyla dijital medyadaki, dijital/sanal kimlikler/benlikler, yanlış sunum için gayet uygun bir araç vazifesi görür. Dijital ortam ise seyirci kitlesinin alanıdır fakat burada kişi hem seyirci hem de aktör konumundadır, çünkü hem gözetleyen hem de gözetlenendir. 


\section{Mekânın Dijitalleşmesi}

Felsefenin kilit ve en temel sorularından olan "varlık" sorunu, insanın bu dünyadaki varoluşunu kavramaya ve anlamlandırmaya yöneliktir. Varlık sorunu kendi başına bir anlam ifade etmekten ziyade, insanı çevreleyen zaman, mekân ve oluş kavramlarıla açılanmaya çalışılmıştır (Şentürk, 2017, s. 102). Mekân içinde, zamanı ve dolayısıyla oluşu barındırması nedeniyle, insanın varlığa dair anlamlandırmasında kritik bir önemdedir, çünkü içine insanı, ilişkileri, zamanı ve en önemlisi hafızayı ve hatırayı alır. Bu nedenle mekân insanda iz bırakır, insanı etkiler. İnsan iletişimi mekânda oluşurken, bu ilişkileri dönüştüren de yine mekânın kendisidir. Mekânın toplumsal ilişkileri oluşturan, yansıtan, iletişimsel eylemleri aktifleştiren aynı zamanda pasifleştiren ve hatta yok eden diyalektik bir yapısı vardır, her mekân insanda Spinoza'nın "duygulanım ve duygulanış" adını verdiği bir etkileşime neden olur.

Modernite ve postmodernite, bireyin ontolojik zaman ve mekân algısını değiştirmiş, dönüştürmüştür. Frederic Jameson (1984b), postmodern dönüşümü mekân ve zaman deneyimimizde bir krize bağlar, bu kriz çerçevesinde, mekânsal kategoriler, bir yandan zaman kategorilerine hâkim olmaya başlar, bir yandan da öyle bir değişim gösterirler ki bu değişime yetişmemiz mümkün değildir (Harvey, 2014, s. 227). Toplumsal teori her zaman toplumsal değişim, modernleşme ve devrim (teknik, toplumsal, politik) süreçleri üzerinde yoğunlaşmıştır. Modernleşmeden beri temel amaç olarak görülen ilerleme miti, toplumsal teorinin konusudur, tarihsel zaman ise birincil boyuttur. İlerleme mekânın fethini, bütün mekânsal engellerin yıkılmasını ve nihaî olarak "mekânın zaman aracılığıyla yok edilmesini" içerir. (s. 232). Bugün söz konusu olan sabit, sınırlara tabi, sürekli bir mekân değil, süreksizliğin sürekliliğgi içindeki mekânın yıkılışıdır, James Joyce'nin söylediği gibi "her türlü mekânın yıkılışını işitiyorum, parçalanan camı ve çöken duvarları, zaman ise son bir kızgın alev".

Bedenin burada ve şimdiliği etrafında düzenlenen gündelik hayat gerçekliğinde, zaman ve mekân farklı yakınlık ve uzaklık dereceleriyle tecrübe edilir. Berger ve Luckmann, insana en yakın olanı, bedenin kolayca ve dolaysızca ulaşabileceği alan olarak görür yani bu alan insanın müdahalesine açık, insan eylemiyle karşılık bulan, insanın içinde bulunduğu "kendi dünyası"dır (par excellence) (Berger \& Luckmann, 2008, s. 35-36). İnsan müdahalesiyle süregiden bu gündelik hayat gerçekliğinde, mekân ve zaman da bireyler için gerçekliğin bir ifadesidir. Klasik mekân anlayışında, fiziksel bir gerçeklik söz konusudur, boyut söz konusudur, yaşam ve insan, iletişim ve işlevselliktir söz konusu olan. Burası belli bir düzene tabidir, fizîken orada olmayı gerektirir. Mekân insanın âidiyet duygusunu geliştirir, kuvvetlendirir, misâl insanın varoluşunda en önemli mekân evidir. Teknolojileri insanın uzantıları olarak gören McLuhan için ev de bedenin genişleyen sınırlarındadır, bunun yanında James Joyce ve Baudelaire evi ikinci bir beden olarak algılarlar (Şentürk, 2017, s. 107). Telgraf ve telefonun başlattığı mekân algısındaki değişim, radyo ve televizyon ile devam etmiş dijitalleşmenin hâkimiyetiyle de somut boyutlarının ötesinde, yeni bir boyuta evrilmiştir. Toplumları imge doygunu bir topluma dönüştüren televizyon, mekânın aşkınlığını simgeleyen ilk büyük teknoloji olarak evlerde konumlanmıştır, artık dünya 
evimizdedir fakat evimiz nerededir? Blum'un internet için söylediği gibi “her yerde ve hiçbir yerdedir". İnternet teknolojisinin dijital araçların ve gündelik hayatın kılcallarında dolanması, bu yersiz yurtsuzluğu evrenselleştirmiştir, sınırlarından kopan imge doygunu dünya kurgusal gerçekliğin, hipergerçekliğin ${ }^{1}$ mekânı haline gelmiştir. Söz konusu olan şey yalnızca fiziki mekân algısının ortadan kalkması değil, aynı zamanda mesafenin de ortadan kalkmasıdır, Baudrillard mesafenin, mesafe pathosunun (duygu yoluyla kavrama) ortadan kaldırılmasıyla, her şeyin üzerine karar verilemez bir duruma büründüğünü ifade eder (Baudrillard, Tam Ekran , 2002). Aynı zamanda mesafenin ortadan kalkması her şeyi ulaşılabilir, dokunulabilir kılmıştır, mükemmeliyetçiliğin saf göstergeleri olarak şeffaflık ve pürüzsüzlük bireyin algısında ve gündelik hayat işleyişinde belirleyici role mâtuftur. Günümüzdeki "pürüzsüz dokunmatik ekranlar" mesafeyi muhafaza eden ve Barthes'in deyimiyle "en büyülü olan görme hissinin" yerine, dokunma hissini ikâme ederek, mesafeyi ortadan kaldıran, gizemin bozulmasına ve her şeyin tüketilebilir-eğlenilebilir kılınmasına sebebiyet veren tüketimin mekânlarıdır (Han, 2018). Küresel enformasyon ağı ile planlanmış ve inşa edilmiş mekân üzerine üçüncü bir mekân mahiyetinde sibernetik mekân bindirilmiştir. Paul Virilio'ya göre, bu mekânın öğeleri "mekânsal boyutlardan yoksundur, anlık bir yayılmanın bireysel zamansallığı içine kazınmıştır. Bu noktadan sonra, insanları artık fiziksel engeller ya da zamansal uzaklıklar ayıramaz. Bilgisayar terminalleri ile video monitörlerinin birbirine bağlanmasıyla birlikte, burası ile orası arasındaki ayrım artık anlamsız hale gelmiştir. Mikroskopla birlikte mikro- makro arasındaki farkın yok olduğu gibi, yakın ile uzak arasındaki fark da ortadan kalkmıştır" (Virilio, 1991, s. 13) . Dijitalleşmenin getirmiş olduğu yeni mekân algılayışı olarak siber-uzam, insanın fiziki görüşünün, dokunuşunun, hissedişinin, sınırının, sosyal ilişkilerinin ve mekânsal gerçekliğinin çok ötesinde yer alır. Siber-uzamı, Rheingold "kelimelerin, insan ilişkilerinin, verinin, zenginliğin ve gücün bilgisayar ortamlı iletişim teknolojilerini kullanan kişiler tarafından ortaya koyulduğu kavramsal bir uzam" olarak; Bell yeni benlikler ve yeni dünyalar inşa eden insanlarla bilgisayarlar arasında yaratılan uzam olarak tanımlar (Uzun \& Aydın, 2012). Siber-uzam burada ve şimdide olmayan lâkin burada ve şimdide olabilecek olana atıf yapar, bu insan sınırının ötesindedir siber-uzamda gerçekten değil hipergerçeklerden-simülakrlardan bahsetmek mümkündür, fakat ortada yüzde yüz gerçek olmayan bir durum da söz konusu değildir, siber-uzam vardır, ulaşılabilir olandır, bu mekânda olan insanlar ve ilişkiler de gerçektir. Siber-mekânlar olarak dijital aygıtlar, ya da dijital aygıtların konumlandığı internet kafe gibi mekânlar siber-uzam için kapı -anahtar vazifesi görürler, bireyler istedikleri an siber-mekânlar aracılığıyla siber-uzama geçiş yapabilmektedir. Siber-uzam fiziki-coğrafi belirlemecilikten, gündelik hayat ve beraberinde getirdiği zamanın ve mekânın gerçekliğinden, burada ve şimdiye dayalı fizîki insan iletişiminden uzak mecralardır. Berman modernizmi, "modern insanların modernleşmenin nesneleri oldukları kadar özneleri de olarak, modern dünyada sıkıca tutunabilecekleri bir yer bulmak ve kendilerini bu dünyada evde hissetmek için giriştikleri çaba" olarak tanımlar (Berman, 2013, s. 11), benzer şekilde toplumdan izole olan bireyler de dijital mecraları "özgürce" hareket edebilecekleri bir mekân olarak görür. Aslında bu boyutsuz-soyut-

\footnotetext{
${ }^{1}$ Simülasyon Kuramını ortaya atan Baudrillard için hipergerçek ya da simülasyon "bir köken ya da bir gerçeklikten yoksun gerçeğin modeller aracılı̆̆ıyla türetilmesi” dir (Baudrillard, 2011) , bundan sonra gerçekten değil, gerçeğin yerini alan simülakrlardan bahsetmek gerekecektir.
} 
ölçülebilir olmayan mekân anlamsal olarak evde ifadesini bulur, çünkü insan ancak evinde en rahat en doğal haliyle bulunabilir, bebek nasıl kendini ana rahminde güvende ve huzurlu hissederse, ev de insanın sığınacağı kendini huzurlu ve güvende hissedeceği mekândır. Bauman insanın içindeyken kendini evinde hissedebildiği yerleri "yakın" kavramıyla açıklar, yakın güven vericidir, "uzak" ise tedirgin edicidir "yakınlık fikri bir sorunsuzluk timsalidir; acı çekmeden edinilmiş alışkanlıklar iş başındadır ve alışkanlık olduklarından, ağırlıklarını hissettirmez" (Bauman, 2010, s. 19-20). Bu durumda siber-uzamda kendini rahat ve sorunsuz hisseden bireyler aslında kendilerini somut evlerinden tecrit etmiş ve soyut siber-uzamı evi gibi sahiplenmişlerdir, benimsemişlerdir. Dijitalleşmeyle birlikte uzak olan soyut olarak, fikrî düzeyde yakınlaşmış ve yakınlı̆̆ın sorunsuz, çabasız, acısız, risksiz deneyimi de beraberinde gelmiştir.

Sanal dünyadaki ontolojik anlam arayışı Second Life oyunu/âlemi/ortamının kullanım amacına benzerdir, burası insanlara yaşamlarını istedikleri gibi şekillendirebilecekleri, yaşayabilecekleri, devam ettirebilecekleri ya da bırakabilecekleri, tamamen insanın kendisine bağlı bir ortam (Turkle, Alone Together, 2011; Dreyfus, 2016) vaadiyle ikinci şans, ikinci hayat olarak kurulmuştur. Second Life'daki bireylerden bir kısmı bu mecrayı oyun olarak görmekten ziyade alternatif özgür bir yaşam biçimi olarak telakki ederler, burası yeni bir varoluş mecrasıdır fakat bu yeni varlık biçiminde sonraları gerçek hayatla çatışma oluşturacak şekilde bir bağımlılık meydana gelebilmektedir. Turkle (2011) bilgisayarların bir araç olmaktan ziyade bir aracı işlevi görmeye başlamasıyla, benliklerin-kimliklerin parçalı, değişken, yeniden oluşturulup deneyimlenebilen özelliklerde olmaya başladığını ifade eder (bu elbette sadece Turkle'ın ifadesi değildir, parçalılık-çokluk-süreksizlik-değişkenlik zaten postmodern düşüncedeki temel kodlardır). Bilgisayar bir araçtan ziyade, Real Life denilen gerçek hayat ile sanal evrende paralel hayat sürdürmeye yarayan bir portal haline gelince çevrimiçi ağlarla yeni "yer" duygusu keşfedilmiştir. Fakat bu durum, insanlar ekrandaki hayatlarına girip çıktıkça gerçek ile sanal arasındaki sınırların aşınmasına sebep oluşturmuştur diğer bir ifadeyle meydana gelen şey insanın gündelik gerçeklikten kopuşu ve kurgusal gerçekliğe hapsoluşudur.

Margaret Wertheim, “Hıristiyanlık'taki cennet anlayışı ile siber-mekân arasında bir benzerlik" kurmuştur. Bu dikkate değer benzetmede Wertheim şöyle der:

Nasıl ilk Hıristiyanlar cenneti maddi dünyanın kaosu ve kokuşmuşluğunun ötesinde, idealleştirilmiş bir âlem olarak hayâl ettilerse - ki bu, çevrelerindeki imparatorluk un ufak olurken fazlasıyla aşikâr bir çözülmeydi- bu toplumsal ve çevresel dağılma çağında, günümüz sibermekân misyonerleri de kendi âlemlerini maddi dünyanın sorunları "üzerinde" ve "ötesinde" bir yer olarak sunuyorlar. İlk Hiristiyanlar cenneti insan ruhunun bedenin zaaflarından ve yanılgılarından kurtulacağı bir âlem olarak tanıtırken, sibermekânın günümüz savunucuları ise sibermekânı benliğin fiziksel bedenin sınırlarından kurtulacağı bir yer olarak ayakta alkışliyorlar. (Margaret Wertheim, "The Pearly Gates of Cyberspace", Architecture of Fear; der. Nan Elin, Princeton Architectural Press, New York, 1997, s. 296, bkz: Bauman, Küreselleşme Toplumsal Sonuçları, 2010, s. 26). 
Siber-mekân cennet anlayışına benzer şekilde, Han'ın "pürüzsüzün dünyası" kavramıyla da ifade edilebilir: "pürüzsüzün dünyası; içinde acının, yaranın, kabahatin olmadığı kuliner (lezzetle ilgili) bir dünyadır, saf pozitifliğin dünyasıdır" (Han, 2018, s. 9). Birey burada negatif bir durumla karşılaşmaz, hayâlini kurduğu ve arzuladığı güzellik karşısındadır, onu rahatsız eden, benliğe meydan okuyan ve onu sarsan bir gerçeklik yoktur, aksi takdirde burası kaçma imkânını içinde barındırır. Siber-uzamda bedenlerin önemi yoktur, ama bedenlerin hayatında siber-mekân ve siber-uzamın kesin ve vazgeçilmez bir önemi vardır (Bauman, 2010, s. 26). Siber-uzam artık bireylerin, hafızaların, kimliklerin, ilişkilerin ve deneyimlerin yerini alan, sürekli kırılgan ve yüzeysel ilişkilerin üretildiği, soyut, boyutsuz ve ölçülemeyen bir uzay alandır. Siber-uzam aynı zamanda Foucault'un ayna metaforuna benzer şekilde hem ütopik bir mekândır yani yeri olmayan yerdir, bireyler burada kendilerini olmadıkları yerde görürler, hem de heterotopik bir mekândır, yani gerçek ile gerçekdışı arasında bir mekân algısı oluşturur, bireyler orada olmadıklarını kendilerine yönelttikleri bakış ile, geri dönüş etkisi ile fark ederler. Heterotopik mekân olan siber-uzamda farklı bireyler, kimlikler, ilişkiler aynı anda bulunabilirler, bu mekânlar bireylerin iradeleri doğrultusunda harekete geçebildikleri sosyalleşme mekânı olabilirken, sınırların aşınması sonucunda rahatlıkla asosyalliğin ve yabancılaşmanın da mekânı haline gelebilirler, bu noktada sosyalleşme anlam dönüşümüne uğrayarak kendi zıttını doğurmuş olur.

Castells (Castells, 2013, s. 526) yeni toplumu, bilgiye dayalı, ağlar etrafında örgütlenmiş, akışlardan oluşan doğası yüzünden enformasyonel bir kent formu olarak değil, akışlar uzamının yapısal hâkimiyetinin izini taşıyan bir süreç olarak görür, sabit bir formdan bahsetmek yerine, akışların sürekliliğine dayanan bir süreç hâkimdir. Toplum, ekonomik ve siyasi sistemler artık akışlar etrafında sürekli şekillenir, enformasyon akışı, finans-sermaye akışı, ses-görüntü ve sembollerin akışı, teknolojinin akışı ve nihayetinde olan şey insanın akışıdır. İnsan bu akış sürecinde, toplumsal- kültürel kodlardan sıyrılır, dağınık ve parçalanmış ağlarla etrafını örer.

\section{Zamanın Dijitalleşmesi}

\subsection{Modernlik- Öncesi Zaman Anlayıșı}

“Zaman” geçmişten günümüze mütefekkirler, âlimler, ilim adamları ve genel olarak insanlar tarafından üzerinde düşünülen, tartışılan muallak bir kavram olmuştur. Zamanın ne'liği, niceliği, niteliği, somutluğu, soyutluğu, varlığı, yokluğu, öncesi-sonrası ve şimdisi üzerine pek çok şey yazılmıştır (Arabi, 2017; Augustinus, 2010; Elias, 2000; Heidegger, 2001). Örneğin İslam mutasavvıflarından İbn-Arabî (Arabi, 2017, s. 380) zaman için "Hasılını öğrenirsen, kuşkusuz zaman gerçektir. $O$, vehimlerle bilinir... Zamanın ve doğanın dış varlı̆̆ı ise yoktur...Tıpk boşluk gibi, ucu olmayan bir uzam"dır der, yine Hristiyan Batı'nın alimlerinden Saint Augustinus için zaman "yokluğa meyli ölçüsünde var olan şeydir", zaman insan için yaratılmıştır ve "Tanrı tarafından zaman yaratılmadan önce zaman diye bir şey" yoktur (Augustinus, 2010). Antik Yunan'a gittiğimizde ise Aristoteles zamanın "düşüncelerimizdeki ard ardalık bilincine ve tecrübe ettiğimiz olaylar arasındaki farklllık duygusuna karşıllk gelmekte" olduğunu, hiçbir değişimin farkında olmadığımızda ise zamanın da farkında olmayacağımızı ifade eder (Kabadayı, 2007). Görüldüğü gibi zaman üzerine tartışmalar 
varlık ve fizik kavramıyla iç içe geçmiştir, bu minvalde zamanın kesin bir tanımını yapmak ya da kesin bir tanımına ulaşmak mümkün görünmemektedir.

İnsanların zamanı yönetme istenci, ilk takvimlerin oluşturulmasından beri doğal koşulların zaruri kıldığı bir durum olmuştur. Özellikle ilk tarım toplumlarıyla birlikte yerleşik düzene geçilmesi, bitkilerin ekim-hasat zamanları- su kenarlarına kurulan yerleşimlerde yaşayan insanların akarsuların taşma zamanını hesaplama zorunluluğu, denizci toplumların medcezir vakitlerini hesaplamaları gibi gündelik ama zaruri işler, ya da ibadet vakitleri gibi geleneksel-dini-kültürel değerler zamanın yönetimini gerekli kılan faktörlerdendir. $\mathrm{Bu}$ yüzden zamanın yönetimini günümüze has bir durum olarak değerlendirmemek gerekir. Fakat modern zaman öncesinde zamanın yönetimi, doğayla ve insanlarla bütünleşik bir yapı taşırken, modernleşmeyle başlayan mekanik zaman algısı, zamanı en ufak saliselerine kadar parçalamış, insanı bu hız ve akışa teslim etmiş ve mecbur bırakmıştır.

Zamanı gece ile gündüzün devinimi olarak gördüğümüzde ise içinde bulunduğumuz dünyanın sınırlarıyla zamanı da sınırlandırmış, özelleştirmiş oluruz, yani zamanı dünyaya atfetmektir bu. Günü 24 saate bölen küresel zaman anlayışı öncesinde, zaman her ülkede, her şehirde güneşin hareketlerine göre farklılık arz ediyordu, zamanın ölçekleri güneş, ay ve yıldızların hareketiydi, toplumda doğal, yerel ve gerçek bir zaman anlayışı söz konusuydu. 1884 yılında yapılan "Uluslararası Meridyen Konferansı" ile dünyanın başlangıç meridyeni yani "0 noktası" olarak İngiltere'nin Greenwich bölgesi seçilmiş, kullanılacak olan uluslararası zaman dilimi de belirlenmiştir. 19.yüzyılda sanayi devrimi ve gelişen haberleşme teknolojileri zaman kavramını da dönüştürmüş, doğa temelli zaman anlayışı yerini, ekonomik temelli mekanik zaman anlayışına bırakmıştır. Bu dönüşüm toplumların gündelik yaşamını temelden değiştirmiştir, artık belirleyici olan gün ışığı değil, küresel ekonomik sistemin işlevselci aracı olarak saattir.

Modernlik öncesi kültürlerde gündelik yaşamın ve toplumun temelini oluşturan zaman hesabında zaman daima uzama bağlı olup, zaman hesabı da sabit ve değişmez değildi, "ne zaman" neredeyse küresel boyutta "nerede" ile ilişkilendirilirdi (Giddens, 2014, s. 24). Mekanik saatin icadı zamanın uzamdan ayrılmasında belirleyici bir faktör olmuş, gündelik hayatın akışı saatin zamanı ile bölünmüştür, artık çalışma zamanı ve boş zaman gibi kavramların saat diliminde kesin bir karşılığı vardı. Yerel, kültürel olan artık standart ve küreseldir, evrensel takvim ve saat ile herkes aynı zamanı yaşamaktadır. Giddens "zamanın boşaltılması" büyük ölçüde, "uzamın boşaltılması" için bir ön koşuldur der, peki bu boşalan zaman ve uzamda insanın konumu nedir, insanı zamandan ve uzamdan ayırmak ne derece mümkündür? Tanpınar'ın söylediği gibi "Saatin kendisi mekân, yürüyüşü zaman, ayarı insandır... Bu da gösterir ki zaman ve mekân insanla mevcuttur !" (Tanpınar, 2008, s. 31). İlk olarak mekanikleşme sonrasında ise dijitalleşme mekân, zaman ve insanın bu birlikteliğini de sorgular hale getirmiştir.

\subsection{Modernlik ve Sonrasında Dijitalleșen Zaman Anlayışı}

Dijitalleşme modern-postmodern bireyin zaman algısında daha köklü bir değişimi meydana getirdi. Dijitalleşen gündelik yaşam işleyişi günün-gecenin ve saatin belirleyici niteliklerini 
gereksiz kılmıştır. A $\breve{g}$ toplumunda geleneksel saatli zaman kavrayışının siber-uzam kapsamında kalktığı rahatlıkla söylenebilir. Gündelik işlerinde zaman bağlı olan insan için artık zamansal sınırların da bir önemi kalmamıştır, 7/24 online bağlantıyı mümkün kılan enformasyon teknolojileri, insanı saatten, saati doğadan bağımsızlaştırabilmektedir. Castells yeni zaman anlayışı için "zamansız zaman" kavramını kullanmaktadır, artık düzensizdoğadan kopuk -döngüsü ve ritmi bozulmuş bir yaşam tarzı ortaya çıkmıştır (Castells, 2013, s. 577). Harvey mekân ve zaman kavramlarının niteliklerindeki devrimci değişimlerin insanın dünyaya bakış açısını da köklü bir değişime uğratabileceğini belirtir, bu durumu "zaman-mekân sıkışması" kavramıyla açıklar:

Mekân telekomünikasyonun yarattığı bir "küresel köy"e ve ekonomik ve ekolojik karşılıklı bağımlılıklardan örülmüş bir "uzay gemisi dünya"ya doğru küçüldükçe ve zaman ufkumuz sonunda içinde bulunduğumuz andan başka bir şey kalmamacasına kısaldıkça (şizofrenin dünyası), mekânsal ve zamansal dünyalarımızın sıkışması duygusunun hakimiyetiyle başa çıkma zorunluluğuyla karşı karşıya kalırız. Zaman-mekân sıkışması deneyimi, insanı kışkırtır, heyecanlandırır, strese düşürür, bazen ağır bir tedirginliğe sürükler; dolayısıyla da çok çeşitli toplumsal, kültürel ve politik tepkileri harekete geçirir. (Harvey, 2014, s. 270)

Yeni enformasyon teknolojileri ile mekânlar uzamının yerini akışlar uzamı almıştır. Geçmiş, şimdi ve gelecek aynı mesaj içinde birbiriyle etkileşim halindedir, bu boyutu ile zaman kavramı da silinir. McLuhan yeni teknolojilerin imkânlı hale getirdiği geçmiş ile şimdinin iç içeliğine yönelik, günümüz insanı için tarih olmadığını, dünyasal olanın önüne hiçbir engel çıkmaksızın mitsel olana dönüşürken, her şeyin şimdiki halde olduğunu söyler (McLuhan \& Powers, s. 42-43). Her şeyin şimdiki halde olması, anı ve hayâl kavramlarını da sorgulatır, bu durumda özlenecek bir geçmiş ya da umut edilecek bir gelecekten bahsetmek de zor görünmektedir. Dijital mekân ve zaman, an ve anıdan bir kopuştur. Artık geçmişin hatırası sabit ve çağrılabilir bir mekâna ve zamana ait değildir, âidiyetlik kalkmıştır, dijitalleşen mekân ve zamanın tüketimi, bireyi seyahat edebileceği Heidegger'in deyimiyle "Hareketsiz Çocukluk Ülkesi"ne götürmekten yoksundur. Sadece anıların yokluğu değil zaman ve mekânın unutuluşudur söz konusu olan. Zaman, Eliot'un ifadesiyle "zaman aracilığıyla fethedilmiştir" ve Baudelaire'nin deyimiyle insan zamanı kullanarak "zamanı unutmuştur". Dijital iletişimi, yüz yüze iletişimden ayıran önemli noktalardan biridir bu aslında. Biri kurumsal olarak, diğeri yüz yüze iletişim kurulan biri tarafından gönderilmiş iki elektronik posta düşünelim. Kurumsal olan, insanda herhangi bir canlılık emaresi, dolayısıyla âidiyet duygusu- duygusal etkileşim ve saklanmaya değer bir his uyandırmazken, diğer posta, mekânsal ve zamansal çağrışımlarıyla, hayâl ve canlılık karışımı bir his ile okutur mesajı, onu saklanmaya değer kılan bu aktif hatırlama yoluyla oluşan canlılık hissidir. Bu nedenle yüz yüze gerçekleşmemiş olan, herhangi bir canlandırmaya neden olmayan iletişim, yer kaplamaksızın insan hafızasından kolaylıkla çıkarılabilir, çünkü burada atfedilen bir insan değeri söz konusu değildir. Sanal mecralarda kurulan iletişimlerin süreksizliği, kırılganlı̆̆1 ve kolaylığı da bundan kaynaklanır.

Bugün dünya toplumlarında dijitale olan bağımlılık sıklıkla çocuklar ve gençler arasında görülmektedir. Bu durumun siyasi-sosyal-ekonomik-dini-eğitim vb. pek çok nedeni olurken, bir nedeni de zamandır, daha genel bir ifadeyle çağ. A $\breve{g}$ toplumu öncesinde çocuklar, anne 
ve babalarının çocuklarıydı, belli bir yere kadar onların yetiştirdikleri ölçülere riayet etmek durumundalardı, kültür ve içinde bulundukları hâl bunu zarurî kılmakla beraber bu yadırganacak bir durum da değildi. Fakat özellikle dijital yerliler denilen, dijital çağa doğmuş olan nesil için bu durum söz konusu değildir, çocuk artık evden, anne-babasından ve hatta kültüründen-toplumundan kopmuştur, çocuk artık sınırlara tabi değildir, tüm bu sahiplenmelerin dışında çocuk artık zamanın çocuğudur. İnsan için zamanın gerçekliği içinde bulunduğu andır, içinde bulunduğu vakittir, içinde bulunduğu hâldir. Günümüz çocuklarının, gençlerinin hâli, ânı, vakti internettir ve gerçeği internet gerçeğidir. Bu durum dijital göçmenler için de artık geçerli olan bir durumdur zaman, ontolojik işleyişini bireylerin gündelik akışlarında hissettirmez, bu hiperzamansallık ontolojik zamanı kapsayıcı bir boyuta ulaşmıştır. Yine ne yazık ki zamanın ve mekânın fiziksel aşkınlığı en üst düzeyde bağımlı gruplarda görülür. İnternet bağımlıları için zaman ve mekân uzamsal bir boyuta hapsedilmiştir. Belki de modern insanın hızlanan zaman algısı bireyin yine kendisini yavaşlatmaya mahkûm etmiştir. İnsan bu yeni toplumsal düzensizlikte zaman idrakini yitirmiştir, zamanın içine doğan insan, zamanın içinde kaybolmuştur. Yaşam süresi uzamış, yaşam kalitesi artmış fakat yaşamın kendisi eksilmiş, içi boşalmıştır. Ahmet Haşim'in söylediği gibi "Çölde yolunu şaşıranlar gibi biz şimdi zaman içinde kaybolmuş kimseleriz."

\section{Bedenin Dijitalleşmesi}

İnsan sosyal bir varlık olarak toplumda 'beden' ile varlığını görünür kılar. Beden dediğimizde aklımıza hiç şüphesiz eti kemiği ile müteşekkil nice cisimler gelecektir, insan bedeni ise diğer cisimlerden bilinciyle ayrılır ve bu noktada kendi cismâniyetini ortaya koyar. Bilincin nesneyle kurduğu bilişsel ilişkide özne kendini var eder, beden ise bilincin oluşmasında aracı bir rôl üstlenerek nesneler kategorisinde görülür. Beden organik yapısıyla oluşturduğu maddi boyutunun ötesinde, aynı zamanda üzerinde pek çok kimliğin de konumlandırıldığı, uygulandığı ve sorgulandığı yapıdır. Toplumsal yapıdaki değerler, değişimler, talepler bedene çeşitli şekillerde yansır bu noktada kültür de oluşturduğu idealler bağlamında bedene ait söylem ve pratikleri tanımlamaya ve düzenlemeye çalışır.

İnsan bedeni çoğunlukla felsefi gelenekte inceleme konusu olagelmiştir, modernlik öncesi beden ve ruh bir bütün olarak ele alınır, bedene yapılan her müdahalenin ruhu da etkilediği düşünülürdü. Daha sonra rasyonel düşünce doğrultusunda Descartes tarafından ortaya atılan Kartezyen görüş, somut ve soyutu- fizik ve metafiziği ayırmış, bu minvalde insan bedeni de, fiziksel beden ve ruhsal beden olarak iki boyutta incelenmeye başlanmıştır.

1980'li yıllar ile birlikte beden, felsefenin yanı sıra sosyolojinin de inceleme konusu olmuştur. Farklı teoriler geliştirilmiş, bedene yönelik farklı okumalar yapılmıştır, Foucault'un 'söylemsel bedeni' Elias'ın 'uygarlaşmış bedeni' geç modernliğin 'dönüşlü bedeni' postmodernliğin 'kutsanmış bedeni' Baudrillard'ın 'hipergerçek bedeni' gibi çalışmalarla beden, sosyolojik bir problem haline gelmiştir (Kara, 2016, s. 24-25). İçinde bulunduğumuz geç-modern postmodern dönemde ise genel olarak beden, tüketim toplumunun merkezinde yer alır. İnsan bedeninin yeni kültürde üç eğilim tarafından etki altına alındığı düşünülür:

“İnsan bedeni bir tüketim aracı olarak her fırsatta yeniden biçimlenir ve moda/yaşam biçimi buna göre değişir. İkinci olarak, çağdaş kültür tüketim işaretlerini, imgelerini ve uyarıcılarını 
kullanarak heyecan ve eğlence oluşturmaktadır. Üçüncü olarak toplumsal hayatta öncekilere benzemeyen bir değerler sistemi ortaya çıkmıştır." (Cirhinlioğlu \& Cirhinlioğlu, 2016, s. 403404)

Bedenlerimiz postmodern düzende tıpkı kimliklerimiz gibi sürekli yeniden inşa halindedir. Bedenin sabit bir formundan söz etmek mümkün değildir, beden sağlık ve moda gibi sektörlerce akışkan, estetik ve pürüzsüz hale getirilir. Doğal formunun benzersiz ve pürüzlü yapısının aksine ideal-kusursuz-aynı güzele odaklı sürekli mücadele alanı olarak doyumsuz ve huzursuzluğun pençesinde biteviye tüketim nesnesine dönüşmüştür. $\mathrm{Bu}$ pürüzsüzleştirmenin ve yeniden inşanın nesnel-somut araçları bedene gündelik gerçeklikte hükmedebilirken aynı zamanda dijitalleşme de bunu ayna-ekran üzerinden gerçekleştirebilmektedir.

Dijital çağa uyum sağlayan dijital bedenler artık "yerleşik bir oluşu" ifade etmez:
"siber-mekânın belli belirsiz gölgesi altında beden hem kutsanmakta hem de hükümsüzleşmektedir... Beden, "her şeyin mümkün olduğu” mottosunun kışkırtıldığı sanal özgürlüklerin etkisiyle sonsuz bir esnekliğe sahip ve dijital kurgu masasında her an her şeye dönüşmeye hazır bir gösteriyi andırmaktadır" (Demir, 2016).

Sınırsız dönüşüm alanı bedene sınırsız bir özgürlük vaad ederken, sınırsız bir huzursuzluk da kapıda beklemektedir. Görselliği ön plana alan töze karşıt, bedene yakın bakış anlayışı bireyin kendisinde hep eksik - kusurlu addedileni göreceğinden bireyin içsel formundaki güzeli de günden günde tüketecektir, kendinde güzel olanı sıfırlayacaktır, bu ise bireyin var olma kudretini günden güne emecektir. Ortaya çıkan ise Demir'in ifade ettiği gibi "hem mutlak bir bedenîleşme hem de bedenin mutlak bir hiçleşmesi" (Demir, Dijital Aşklar: Sanallık ve Gerçeklik Arasında Bedenin, Mekânın ve İletişimin Tasarımı, 2016) olacaktır.

Her şeyin en ufak parçalara ayrılabildiği dijital datacılık, bedende de zuhur etmiş, bedeni dijital data kümelerine bölmüştür, bölünme ölçülebilir ve nicelendirilebilir olanı beraberinde getirmiştir. Han'ın "Nicelenmiş Kendilik" adını verdiği beden, kontrol ve gözetim ekranına dönüşmüştür, ağ toplumunda, dijital ağ bedeni de 'ağ'laştırmıştır (Han, 2018, s. 15). Gözetim ekranına dönüşen beden, enformasyon ağının uçsuz bucaksız uzamına kendi rızasıyla çekilmektedir, savunmasız ve dirençsiz kalan bedenin, "süper-panaptikon"ª karşı sığınabileceği bir limanı yoktur. Bedenin kendisi hem veri kaynağı hem de alıcısı durumundadır, McLuhan (McLuhan \& Powers, 2001), sürekli ışık hızında yaşayan ve veri yağmuruna tutulan bedenin şişirici ya da şizofrenik bir hale neden olabilecek bir "içe patlama" durumu yaşayacağını söyler. Böylece "bedeni bir yerde olacak, ama zihni veri bankasının her yerinde tek bir anda olmak üzere elektronik boşluk içinde yüzecektir. Bedenini yitiren insan bir astronot kadar ağırlıksızdır, ama çok daha hızlı hareket edebilir" (McLuhan \& Powers, 2001, s. 161). Mekanik çağda mekân boyunca uzanan bedenin uzantıları, bugün dijital çağda, dijital beden ile zaman ve mekânı dışlayarak merkezi sinir sistemimizi uzatır. McLuhan (McLuhan, 1994: 3) artık insan uzantılarının son safhasına yani "bilincin teknolojik simülasyonuna" yaklaşmakta olduğumuzu ifade eder. Beden enformasyon teknolojileri ile fiziksel konumunu terk etmeksizin hareket edebilir. Çevre - merkez

\footnotetext{
2 “Süper-panoptikon'un Panoptikon'dan tek farkı, gözetim altındakilerin, gözetimin birincil —ve gönüllüunsuru olmalarıdır" (Bauman, Küreselleşme Toplumsal Sonuçları, 2010, s. 55).
} 
ayrımının yok olması ile ontolojik varlık anlayışı geçersizleşmekte, beden akıllı cep telefonları- sosyal medya mecraları gibi iletişim ortamlarında aynı anda birkaç yerde olabilmektedir. Siber uzay alanında yapılan biyo-teknolojik deneylerle aynı anda iki ayrı yerde ve bedende yaşayabilmenin imkânları da araştırılmaktadır (Şentürk, 2017, s. 120-121). Böylece beden ve kişilik ikileşecek, gerçek beden yerini, hipergerçek bedene birakabilecektir, dijitalleşen-sanallaşan-hipergerçek beden varlığının merkezi özne konumundan sıyrılmış olacaktır.

\section{Dijitalleşmenin Mekânı Olarak: Beden}

Beden hem siber-uzamda dijitalleşme imkânını bulur hem de dijital teknolojilerle donatılan gündelik hayatta dijitalleşmenin mekânı haline gelerek somut ve soyut boyutlarıyla dijitalleşmiş olur.

Teknoloji artık bedenlerin ayrılmaz bir parçasıdır, bedenin uzantısından daha fazlasıdır. Giyilebilir teknoloji, bedene ontolojik bir beden algısından farklı bakılmasına neden olur, burada söz konusu olan şey bireyin benlik duygusunun değişimidir. Her birey için aynı anlama tekabül etmeyen teknoloji, bazı bireyler için sadece enformasyona ulaşmanın ve hayatı deneyimlemenin teknik bir aracı değil, çok daha derin bir anlama karşılık gelmektedir: kişinin bedenine. Teknolojiyi bedeni olarak addeden bu algıya sahip bireyler, teknolojiyle kendilerini daha özgüvenli, başarılı ve daha iyi bir insan olarak hissederler, teknolojisiz olmak adeta "çıplak olmak" gibidir (Turkle S. , 2005, s. 5). Bu hızlı teknoloji çağında, bireyler, iletişim araçlarından ayrılarak, kendi başlarına düşünmeye ihtiyaç duyarlar, düşünmek için ayrı bir zamana ihtiyaçları vardır. Fakat bu durum, iletişim araçlarının, bireyin beden algısıyla her gün daha da yakınlaştığı günümüzde çelişkili bir durum ortaya çıarır, birey giderek iletişim araçlarını zihnin bir uzantısı gibi hissetmeye başlar (Turkle S. , 2008, s. 132). Özelleştirilebilir teknolojik aygitlar ile bedenin sürekli yakınlığı sonucu bireylerde "ikinci bir ben" - yeni bir benlik durumu- deneyimlenir (Turkle S. , 2008, s. 121). Bireyin dijital dili, ve yeni konumu teknolojik aygitların diliyle belirlenir, örneğin "telefonda olacağım" öznenin konumunu belirleyen bir yapıya sahiptir, burada ifade edilmek istenen teknolojik aygıtın "açık" olacağı ve bireye telefon aracılığıyla ulaşılabileceği, bireyin telefonda sosyal olarak var olacağıdır. "Cep telefonunda, çevrimiçi, Web'de, anlık mesajlaşmada" - gibi ifadeler Turkle'ın ifadesiyle "bağlı bir benlik durumu"nu gösterir. Artık "Her zaman açık / her zaman seninle" (always-on/always-on-you) olan iletişim cihazlarımıza ve onlar aracılığıyla ulaşacağımız insanlara ve şeylere bağlıyızdır, bağlantılı olmaları bu cihazları bizim için canlı kılar (Turkle S. , 2008, s. 122).

Bedeni dijitalleştiren teknolojiler gün geçtikte boyutlarını-sınırlarını genişletmektedir. İlk olarak bedeni, fikrî boyutta ele geçiren teknolojik aygıtlar, bedenin de yüzey alanıyla sınırlı kalmamakta derinin içine nüfuz etmektedir. Bunun bir örneği olarak vücuda enjekte edilebilen-edilebilecek çipler verilebilir. Günümüz insanı gerek gündelik hayatta şahsî kullanım alanlarında, gerek çalışma hayatında pek çok parola/pin/şifre kullanmak durumundadır, kullanım kolaylığı amacıyla kişisel güvenlik bilgilerini içeren deri altına enjekte edilen mikroçipler üretilerek, çalışanlar çeşitli güvenlik bölgelerine girebilir, parolasız dijital araçlara erişim sağlayabilir hale gelmiştir (Mosco, 2017, s. 98). Beden 
üzerinde bir diğer belirleyici güç olan moda da yine teknoloji aracılığıyla beden üzerindeki hâkimiyetini güçlendirmektedir. "Cildinizin görünüşünü değiştirmekten daha iyi bir moda ifadesi olmadığını düşünüyorum" bu sözler, 2017'de, MIT'in Dijital Teknoloji Deneyimi, İnovasyon ve Geliştirme'deki Vatikan Medya Laboratuvarı'nda tanıtılan "DuoSkin" için estetik ve işlevselliğin evliliğinden bahseden bir geliştirici tarafından söylenmiştir. Bahsedilen moda anlayışı, elektronik cihazlarla bağlantılı olarak vücut ısısına göre de değişebilen geçici dövmeler üzerinedir. Bununla birlikte veri okuma, giriş kontrol vb. özelliklere sahip olan bu cihazın ucuz üretimi nedeniyle yaygınlaşması da kolaydır, böylece ucuz ve basit yollardan bir moda ifadesi olarak tanitımı yapılır (Mosco, 2017, s. 97). Benzer şekilde, hava koşullarına adapte olabilen akıllı montlar, renk ve model değiştiren dijital elbiseler, akıllı bileklikler-saatler, tehlike durumunda ilgili otoriteleri bilgilendiren akıllı takılar, uzun yol şoförlerini uyanık tutan şapkalar gibi giyilebilir teknolojilere daha pek çok örnek verilebilir. Bu örnekler gelecekteki internet sistemine, politik ve ekonomik amaçlara ulaşmaktan daha fazlasına, "Nesnelerin İnterneti"ne temel olarak görülen adımlardır (Mosco, 2017, s. 100). Nesnelerin İnterneti, nesneler ve canlı organizmaların aktivitesini, İnternet dâhil, ağlar üzerinden veri toplayan, işleyen ve raporlayan sensörler aracılığıyla ölçen, izleyen ve kontrol eden bir sistemdir, bireyler ve toplum üzerinde derin bir etki vaat eder (Mosco, 2017, s. 39-40). Nesnelerin İnterneti denildiğinde, sadece nesnelerin birbirine bağlanabildiği bir yapıdan değil insanların da nesnelere bağlanabildiği bir ağdan söz etmek gerekir. Günümüzde pek çok ürünün nesnelerin internetine dâhil olduğunu bilmekle birlikte gelecekte cihaz-insan bağlantısının devâsa boyutlara ulaşacağını tahmin etmek de zor değildir. Ortak terim burada "akıllı ve bağlı" olacaktır, akıllı kilit- akıllı ev-akıllı termostatakıllı güvenlik sistemi vb. Örneğin "Healthpatch Sağlık Monitörü" bireyin herhangi bir sağlık merkezine gitmeksizin sağlık muayenesini yapabilirken, bireyin EKG'sini çekebilir, kalp atışı ve solunum hızını- vücut ısısını vb. değerlerini ölçebilir. Bu tür cihazlardan bazıları, sağlık izlemesini iyileştirmek için cildin içine gömülüdür ancak implantlar da sürveyans ${ }^{3}$ (surveillance) derinleştirmeyi amaçlar. İsveç'te binlerce vatandaş kimlik kartı, kredi kartı gibi şahsî eşyalarını taşımamak ve parola hatırlama ve parola girme gereksinimini ortadan kaldırmak amacıyla deri altına çip enjekte ettirmiştir, bu uygulama şirketlerin de çalışanlarının parola gereksinimlerini ortadan kaldırmak için başvurdukları bir yoldur fakat bu aynı zamanda otoriteler için denetimi de sürekli ve güvenli hale getirmektedir. Gelecekte giderek artacağı öngörülen "nesnelerin interneti" nesnelerin tüketiminin de teminidir, bunun ise vazgeçilmez ön koşulu, bedenin tüketim nesnesi olarak aktivitesini sürdürmesidir, böylece beden giderek dijitale gömülü bir yapıya bürünür.

\section{6. İletişimin Dijitalleşmesi}

Tarihte ilk kez iletişim olgusunu kendi başına sözlü ya da yazılı olarak ele alamıyoruz, dijitalleşme yazılı, sözlü, görsel-işitsel formları bütünleştiren bir meta-dil ve hipertext oluşturmuştur. İnsan ruhu, boyutlarını beynin, makinelerin ve toplumsal bağlamların arasında yeni bir etkileşimde birleştirerek iletişimin karakterini tümüyle değiştirmiştir

\footnotetext{
${ }^{3}$ Verilerin sistematik olarak toplanması, işlenmesi ve elde edilen sonuçlara göre harekete geçecek kişilere ve ihtiyacı olanlara bu değerlendirmelerin hızla geri bildiriminin sağlaması süreci.

( https://www.afad.gov.tr/tr/23792/Aciklamali-Afet-Yonetimi-Terimleri-Sozlugu?kelime=s\%C3\%BCrveyans)
} 
(Castells, 2013, s. 440). Genel olarak kültür ve özelde iletişim kültürü insanı ve toplumları şekillendiren bir kuvvettir, kültürler iletişimle başlayıp, iletişimle aktarıldığı için, iletişimin dönüşümü kültürü de dönüştürmüştür, yeni teknolojik sistem iletişimin boyutlarını başkalaştırmıştır. Dijital iletişim, dijital dili de ortaya çıkarmış, simgesel-imgesel -göstergesel evrensel bir dil sanal mecralardan sonra gündelik hayatta da hâkim olmaya başlamıştır, örneğin en basit şekilde "emoji" denilen ifade simgeleri, tüm dünyada evrensel-ortak bir anlama karşılık gelmektedir. Özellikle dijital dünyaya doğmuş olan ve ilk kez Prensky tarafından kullanılan "dijital yerliler" (Digital Native) denilen Y kuşağı (1980-2000 arası doğanlar) ve Z kuşağı (2000 ve sonrasında doğanlar) dijital dünyaya oldukça hakimlerdir, iletişimlerinde ortak bir dil oluşturabilmiştir, bu dil dijitalin dilidir, Prensky'ye göre $Y$ ve $Z$ kuşağının anadilleridir (native speaker) (Prensky, 2001).

İnsanların maddi ve manevi ihtiyaçlarını dünya çapında işleyen bir makineye dayanarak giderdiği, yakın gelecekte geçen E.M.Forster'ın "The Machine Stops" adlı eserinde anne ve evladı arasında dijital iletişim araçları aracılığıyla geçen bir konuşmada, annenin sitem vâri sözlerini görürüz: "Makine çok şeydir, ama her şey değildir. Senin gibi birini görüyorum... Ama seni görmüyorum. Bu telefonla senin gibi birini duyuyorum ama seni duymuyorum. Bu yüzden gelmeni istiyorum"4 , "karşılıklı konuşmanın hakîkî özünü makine anlayamaz" (1985).

Burada kuşak çatışmasını görebilmemiz de mümkünken, asıl olan dokunsal iletişim ile sanal iletişimin çatışması ve birbirlerinin yerlerine ikame olunamayışlarıdır. Dijital iletişim, insanı insana bir araçla bağlayan, sözleri, sesleri ve görselleri uçucu anların nesneleri haline getiren dokunaksız karşılıklı bir iletimdir. Mekânsal- zamansal kısıtlamalara takılmadan erişimi mümkün hale getirmesi kısmen olumlu bir durum olabilse de, fizîken ulaşılabilecek olana sıklıkla dijital araçlarla ulaşmak, beraberinde bir doygunluğu getirir, bu ise özlemi ve merakı gideren durumdur, Baudrillard'ın söylediği gibi “ölümcül olan doygunluktur".Her kolaylaştırma, erişilenin-ulaşılanın değerini hafifletir, bunu algılamak ise sorgulama yoluyla gerçekleşir. Gündelik hayatın telaşı, bireylere bu sorgulama imkânını unutturur, fakat bu sorgulama imkânsız değildir. Birey "ulaşmak" istediği an bu edimi düşünmeyi değil gerçekleştirmeyi hedefler, önemli olan o andır, hız ve arzu aracı sadece işlevselleştirmiş olur. Modernlik çelik ve betonla inşa ediyordu; postmodernlik ise plastikle (Bauman, 2018, s. 116), eskinin güçlükle ve emekle inşa edilen iletişim süreçleri, toplumsal ve bireysel ilişkileri, postmodernitenin plastik ve şeffaf ilişki örüntülerinde kısa sürede yapılandırılır fakat kırılgan ve süreksiz kılınır. Elektronik iletişim formu, yüz yüze teması yalnızca gereksiz hale getirmez aynı zamanda onu atomize de eder, bu ise dijital kimliklerin sayısal, bölünebilir, silinebilir ve çoğaltılabilir olmasının hem nedeni hem de sonucu olarak değerlendirilmelidir (Demir, 2016).

McLuhan'ın, insan eliyle oluşturulmuş bütün yapıları insan bedeninin uzantıları olarak görmesi (McLuhan \& Powers, 2001, s. 123), dijital medyada had safhada ortaya çıkar, gündelik yaşamda konuşmaya imkân bulamayan veya konuşacak insan bulamayanlar dijital mecrayı duyma-görme-dokunma ve konuşma ihtiyacını giderebilecekleri bir alan olarak

\footnotetext{
${ }^{4}$ Metnin orjinali: "The Machine is much, but it is not everything. I see something like you in this plate, but I do not see you. I hear something like you through this telephone, but I do not hear you. That is why I want you to come."
} 
deneyimlerler. Yapay olan bu mekânlarda, konuşmak ihtiyacı-hissi, yapay olan yazı ile giderilir. Dijital dünyayı daha insanî olarak yapıntı mekânlar haline getiren ve insanların buralarda kümelenmesine-nefes almasına imkân tanıyan önemli bir özellik ise görsel ve işitsel içeriklerdir, yani videolardır, çünkü görmek-duymak-hareket etmek canlılığa delâlettir. McLuhan, bütün insansal teknolojilerin etimolojisinin bedenin kendisinde bulunması gerektiğini ifade eder (s. 73), insan bu mekânlarda, cansızlaşan yaşamlarını canlılaştırmak niyetindedir, Ong'un söylediği gibi "Teknoloji yapaydır ve - yine bir paradoksyapaylık insanların doğal bir parçasıdır." (Ong, 2012, s. 102).

Medyanın bütün biçimleri McLuhan'ın dörtlü metaforuna maruz kalır, yani, medyalar bir takım şeyleri ön plana çıkarırken, bir takım şeyleri de ıskartaya çıkartır, ayrıca medyalar uzun süre önce bırakılan bir unsur ya da aşamayı tekrar öne çıarırken, kendi potansiyel limiti dışına çıkarıldığında tadilata ya da tersine çevirmeye uğrarlar (McLuhan \& Powers, 2001, s. 16). Bu durumu ister teknolojik aygitlar üzerinden inceleyelim ister dijital ortamlar üzerinden inceleyelim istersek de insanın dijitalleşen iletişimi üzerinden inceleyim sonuç aynıdır. Örneğin bir sosyal medya olan Facebook, kendinden önce ortaya çıkmış olan Myspace'yi ıskartaya çıkarırken, tanıdıklarla gerçek hayatta buluşma imkânının giderek kısıtlandığı "hız" çağında, yeni bir buluşma noktası haline gelebilmiştir. Fakat aynı mekân kişisel hesabında sayısız insanı içeren kişiler için, bir iletişim-sohbet-buluşma durağı-noktası değil, belki bir trafik lambası haline gelmiştir. Gerçek hayatta da, kişinin hayatında ne kadar çok insan varsa o kadar büyük de bir yalnızlığı vardır, çünkü insan herkese yetmeye kadir olamadığı gibi yalnız kendine yetmeye de kadir değildir, bunun orta yolunu bulmadığı takdirde ya somut olarak yalnızlaşacaktır ya da kalabalıklar içinde yalnızlığı yaşayacaktır.

Günümüzde dijital iletişimin önemli bir özelliği de geleneksel hiyerarşik ayrımların çok daha rahat ortadan kaldırılabildiği mecralara imkân sağlamasıdır, bu heterotopik mekânlar, Bakhtin'in karnaveleks ortamlarını andırır, Bakhtin karnaveleksi gündelikle iç içe görür, onun için karnavaleks tını hayatın her gününde var olur. Karnavaleks ortamlar bireyler arasındaki tüm hiyerarşik pozisyonlara karşı yeni bir ilişki kurma ortamıdır, aşina ve özgür bir tutum tüm değerler, şeyler ve olayların, herşeyin üzerine yayılır. Karnavaleks imge "kutsalı dünyeviyle, yüceyi aşağıyla, önemliyi önemsizle, bilgeyi aptalla bir araya getirir, birleştirir, ilişkilendirir ve birbirine bağlar" (Bakhtin, 1999, s. 123). Dijital, sanal dünyalar da Bakhtin'in karnavaleks ortamları gibi, toplumsal gerçeklikte yer alan tüm hiyerarşilerin, ayrımların, farklılıkların önemsizleştiği ve herkesin bu verili kimliklerden sıyrılarak bir arada bulunabildiği özgürleşme mekânlarıdır (elbette her özgürleşmenin bir tutsaklığı da beraberinde getirdiği unutulmamalıdır).

Dijital dünya, gündelik hayatında diyalojik iletişim sürecinden mahrum kalmış yabancılaşmış insanın uğrak yeridir. Dostoyevski yalnızlığın olanaksız olduğunu ve doğasında bir yanılsamanın bulunduğunu düşünür, onun için "olmak, iletişim kurmak demektir. Mutlak ölüm (var olmama); işitilmeme, tanınmama, hatırlanmama halidir" (Bakhtin, 1999, s. 287). Dolaysız iletişimini sürdüremeyen yabancılaşmış insan, buradalığına, benliğine dair sanal dünyayı araçsallaştırır. Kendini gündelik hayatta gerçekleştirememek, şimdi ve burada olamamak sanal mecrayı diyalojik iletişim için bir kurtuluş mekânı haline getirir, çünkü söz işitilmek içindir, buradayım demek içindir. Yalnızlaşmış bireyler (örn.Hikikomori) toplumsal gerçeklikten, gündelik hayattan kopmuş, fakat bu bağlantıyı bir 
üst noktaya taşımışlardır: Sanal mecraya. Kendilerini soyutladıkları gündelik yaşamın tüm geleneksel, kültürel, ideolojik, ekonomik olgularına, belirlemeciliklerine kendi içinde katı bir direniş, karşı duruş ortaya koyarlar. Kendine sanal- sürrealist- hipergerçek bir dünya oluştursa dâhî izole olan birey, varoluşunun belki bir gereği belki bir kanıtı olarak, bu dünyayı iletişim mekânı haline getirir, bu ise Bakhtin'in “kendimi en başta ötekiler yoluyla gerçekleştiriyorum: Kendime dair ilk fikri oluşturabilmek için onlardan sözcükler, formlar, tonlamalar alıyorum... Benliğe dair her şey ötekilerin sözlerinden geçer" (Bakhtin, 1999, s. 287) sözlerini hatırlatıyor. Oysa kendini sanal mecrada ötekiler yoluyla gerçekleştirmek başkasına/ötekine hapsolmaktır. Ötekinden, ötekinin baskısından kaçan birey Baudrillard'ın deyimiyle "en çok kaçtığı şeye yakalanmıştır" bile. Postmodern durumda, hipergerçek bir ortamda kendini sanal dünyanın diğer milyonlarca ötekisi gibi nesneleştirerek, düzenin devamını en uysal şekilde sağlar, o artık gündelik hayatın gerçekliğinde boğulmuş sanal dünyanın bir ötekisidir.

Dijital dünyanın sanal bireyleri modernitenin hiyerarşik özne-nesne paradigmasının ötesine geçerek, "nesne-nesne" paradigmasında, nesneler dünyasında kendilerini konumlandırmış olurlar, bireye dair ne varsa enformasyonel bir metaya dönüşür. Gündelik hayatın aksine, sanal evren diyalojik bir ilişkinin kurulacağı mecra olmaktan çok uzaktır. Bununla birlikte, ağ toplumuna dönüşen yeni toplumsal düzende, iletişimin-haberleşmenin küresel boyutlarda dijitalleşmesi kaçınılmazdır, burada dikkat edilmesi gereken şey, dijital iletişim sürecinin insanın tüm diyalojik ve monolojik iletişim süreçlerini kapsamamasıdır.

\section{SONUÇ}

İnsanın kendine ve topluma bakışı, saf bir bakış değildir, sürekli olarak geçmişin ve şimdinin izlerini taşıyan, mevcut kültürel değerlerden etkilenen dolaylı bir bakıştır. Geleneksel toplumdan modern topluma geçiş ile insan zihni ve algısı ile gündelik yaşam pratiklerinde meydana gelen radikal dönüşüm, dijital toplumda hızla devam etmiştir. Dijitalleşmeyle sarmalanan bireyin tutum ve davranışları ile kendine ve topluma bakışı da bu ölçüde şekillenmektedir. Modern birey, bedenine, kimliğine, zaman ve mekân kavramina dijitalleşme ekseninde bir bakış sunmakta, iletişim ise bu bakışı gündelik hayat pratiklerinde görünür kılarak, diğer tüm sosyal-ekonomik-siyasi etmenlerle birlikte dijital kültürü oluşturmaktadir.

İnsanın varlık sorgulamasının karşılık geldiği bir yapı olan kimlik, modernlikte sabit ve tutarlı bir hale getirilmeye çalışılırken, post-modernlikte akışkan, kırılgan, sınırsız ve belirsiz bir forma bürünmüştür. Dijitalleşme ile sanal mecralara taşınan birey, sürekli bir yinelemeye tâbi olan kimliğin sanal varyasyonlarını üretmektedir. Dramaturjik performansı ve idealize edilen benliği sunmak maksadıyla, toplumsal gerçeklikten kısmen veya tamamen arındırılan sanal kimlikler dijital bir vitrin mahiyetinde sergilenmektedir. Kutsanmış benliğin göstergesi olan sanal kimlikler, gerçekliğe dair kuvvetli bir yanılsamadır.

Zaman kavramı insanlığın her evresinde merak ve tartışma konusu olagelmiştir, fakat modernlik öncesi ve sonrası arasında gözle görülür bir fark vardır: Zaman uzama bağlı ve bütünlükçü yapısından tecrit edilmiş, mekanik saat ile fragmanlaşmıştır. Dijitalizasyon ise 
siber-uzama taşınan gündelik hayat işleyişinde, insanı mekanik/ saatli zaman anlayışından, zamanı ise doğadan bağımsızlaştırarak (Castells'in deyimiyle) "zamansız zaman" anlayışını ortaya çıkarmıştır. Ritmini ve düzenleyiciliğini kaybeden zaman, gündelik yaşamı da ritimsiz ve düzensiz kılmıştır. Bu dağınık yapıda zaman anlam kaybına uğramış, içi boşalmıştır, insan ise kayıp zamanın içinde şimdiye hapsolmuştur.

Fiziksel, boyutsal dolayısıyla yerleşik bir gerçekliğe gönderme yapan klasik mekân anlayışı dijitalleşme ekseninde soyut, boyutsuz ve akışkan siber-uzama evrilmiştir. Mekânın yersiz yurtsuzlaşması, bireyin de yersiz yurtsuzlaşmasııı ve yabancılaşmasını beraberinde getirmiştir. Birey için yakın'a tekabül eden "ev", artık biçimsiz bir uzamdır. Sınırların tükenişi, sorunlu bir özgürlük mitini doğurmakta, birey ise dolaysız erişimin hazzını yaşamaktadır. Bedenin hareketinden, zaman ve mekânın mesafesinden bağımsızlaşan birey, hipergerçek siberuzami "fethetmektedir".

Beden, içinde konumlandığ1 sistemin değerlerinden beslenerek "kültürel ayna" vazifesi görür, bu nedenle kültürel değişimler ve dönüşümler bedene doğrudan veya dolaylı olarak yansır. Modernitenin "idealleştirme" mitiyle halkalanmış beden, pürüzsüz görünürlüğü, dijitalleşmenin döngüselliğinde biteviye inşa ederek hipergerçeğe dönüşmektedir. "Dijital datacılı" ile beden dijital data kümelerine bölünmüş, sabit-bütünlükçü yapısından arındırılmış, gözetim ve kontrolün ekranı haline gelmiştir. Modern kültürde "benliği yüceltmenin bedeni yüceltmek" olarak karşılık bulması (Demir, 2017, s. 10), dijitalleşmeyle beraber siber-uzamda da görünür kılınmıştır. Dijital formasyonda beden hareket etmeksizin her an ve her yerde bulunabilmenin acısız, sorunsuz (!) tatminini deneyimlemekte, aynı zamanda hem sanal evrende dijitalleşmekte hem de gündelik hayatta, nesneler internetinde dijitalin mekânı haline gelmektedir. Beden dijital kültürün devamı için elzem bir tüketim unsuruna dönüşmektedir.

Dijitalleşme, gündelik hayat pratiklerini şekillendirmek ve dönüştürmekten ziyade yönetmektedir, bu yetkinliğini ise birey, toplum, devlet ve küresel sistem dâhilinde gerçekleştirmektedir. Gündelik hayatı ' $a \breve{g}^{\prime}$ laştıran dijitalleşmenin hem birey hem de toplum nezdinde müspet sonuçları olabilirken, özünde bir çatışma unsuru olarak yabancılaşmayı ve yalnızlı̆̆ı getirdiği de açıktır.

Kaynakça

Alemdar, K., \& Erdoğan, İ. (2005). Öteki Kuram: Kitle İletişim Kuram ve Araştırmalarının Tarihsel ve Eleştirel Bir Değerlendirmesi. Ankara: Erk .

Arabi, İ. (2017). Fütühat-ı Mekkiyye (Cilt 2). (E. Demirli, Çev.) İstanbul: Litera.

Augustinus. (2010). İtiraflar. (Ç. Dürüşken, Çev.) İstanbul: Kabalcı.

Bakhtin, M. (1999). Problems of Dostoevsky's Poetics. Minneapolis, London: University of Minnesota Press.

Baudrillard, J. (2002). Tam Ekran . (B. Gülmez, Çev.) İstanbul : Yapı Kredi Yayınları.

Baudrillard, J. (2011). Simülakrlar ve Simülasyon. (O. Adanır, Çev.) Ankara: Doğu Batı .

Bauman, Z. (2010). Küreselleşme Toplumsal Sonuçları. (A. Yılmaz, Çev.) İstanbul : Ayrıntı . 
Bauman, Z. (2018). Parçalanmış Hayat "Postmodern Ahlak Denemeleri". (İ. Türkmen, Çev.) İstanbul: Ayrintı.

Berger, P., \& Luckmann, T. (2008). Gerçekliğin Sosyal İnşası "Bir Bilgi Sosyolojisi İncelemesi". (V. S. Öğütle, Çev.) İstanbul: Paradigma Yayıncılık.

Berman, M. (2013). Katı Olan Her Şey Buharlaşıyor. (Ü. Altuğ, \& B. Peker, Çev.) İstanbul: İletişim.

Borlandi, M., Boudon, R., Cherkaoui, M., \& Valade, B. (2011). Sosyolojik Düşünme Sözlüğ̈̈. (B. Arıbaş, Çev.) İstanbul : İletişim.

Campbell, R., Martin, C. R., \& Fabos, B. (2012). Media \& Culture (8 b.). Boston: Bedford/St.Martin's.

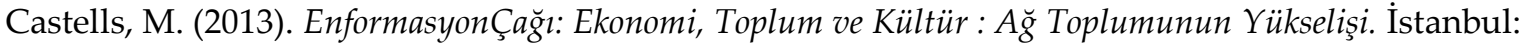
İstanbul Bilgi Üniversitesi Yayınları.

Chayko, M. (2018). Süper Bağlantılı Internet, Dijital MedyaETekno-Sosyal Hayat. (B. Bayındır, D. Yengin, \& T. Bayrak, Çev.) İstanbul: Der Yayınları.

Cirhinlioğlu, Z., \& Cirhinlioğlu, F. (2016). Postmodern Sağlı̆̆ın Yükselişi ve Düşüşü. K. Canatan içinde, Beden Sosyolojisi (s. 395-411). İstanbul: Açılımkitap.

Demir, S. T. (2016). Dijital Aşklar: Sanallık ve Gerçeklik Arasında Bedenin, Mekânın ve İletişimin Tasarımı. TRTAkademi, 510-527.

Demir, S. T. (2017). Ten Medeniyeti "Modern Kültürde Beden ve Ötesi" . İstanbul: Açılım Kitap .

Dijital Ajanslar . (tarih yok). Nisan 15, 2019 tarihinde http://www.dijitalajanslar.com/: http://www.dijitalajanslar.com/araclar/giyilebilir-teknolojiler/ adresinden alındı

Dreyfus, H. L. (2016). İnternet Üzerine. (V. M. Demir, Çev.) İstanbul: Küre Yayınları.

E.M.Forster. (1985). The Machine Stops . Londra: Sidgwick \& Jackson .

Friedman, L. M. (1999). The Horizontal Society . New Haven and London : Yale University Press.

Gardiner, M. (2016). Gündelik Hayat Eleştirileri. (D. Özçetin, B. Taşdemir, \& B. Özçetin, Çev.) Ankara: Heretik Yayınları.

Giddens, A. (2014). Modernliğin Sonuçları. (E. Kuşdil, Çev.) İstanbul: Ayrıntı.

Goffman, E. (2016). Günlük Yaşamda Benliğin Sunumu. (B. Cezar, Çev.) İstanbul: Metis.

Han, B.-C. (2018). Güzeli Kurtarmak . (K. Filiz, Çev.) İstaanbul: İnsan Yayınları.

Harvey, D. (2014). Postmodernliğin Durumu. (S. Savran, Çev.) İstanbul: Metis.

Kabadayı, T. (2007). Eskiçağda ve Ortaçağda Başlıca "Zaman" Öğretileri. Felsefe ve Sosyal Bilimler Dergisi, 155-166.

Kara, Z. (2016). Beden Sosyolojisinden Ölüm Sosyolojisine: İnterdisipliner Bir Yaklaşım. K. Canatan içinde, Beden Sosyolojisi (s. 23-95). İstanbul: Açılımkitap Pınar Yayınları .

MailOnline. (2018, October 23). April 17, 2019 tarihinde www.dailymail.co.uk: https://www.dailymail.co.uk/sciencetech/article-6306569/Thousands-Swedes-gettingmicrochip-IDs-inserted-hands.html adresinden alınd 1

Martin, E. (1994). Flexible Bodies . Boston: Beacon Press. 
McLuhan, M., \& Powers, B. (2001). Global Köy. (B. Ö. Düzgören, Çev.) İstanbul: Scala Yayıncılık.

Mead, G. H. (2017). Zihin, Benlik ve Toplum. (Y. Erdem, Çev.) Ankara: Heretik.

MediBioSense. (2018). April 17, 2019 tarihinde www.medibiosense.com: https://www.medibiosense.com/healthpatch/adresinden alındı

Mosco, V. (2017). Becoming Digital "Toward a Post-Internet Society" . Bingley : Emerald Publishing.

Olcay, S. (2018, Nisan). Sosyalleşmenin Dijitalleşmesi Olarak Sosyal Medya ve Resimler Arasında Kaybolma Bozukluğu: Photolurking. Yeni Medya Elektronik Dergi, 90-104.

Ong, W. J. (2012). Sözlü ve Yazılı Kültür - Sözün Teknolojileşmesi (6. b.). (S. P. Banon, Çev.) İstanbul: Metis Yayınları.

Postman, N. (1993). Technopoly. New York: Vintage Books.

Prensky, M. (2001). Digital Natives, Digital Immigrants. On the Horizon, 9(5).

Şentürk, R. (2017). İletişim ve Televizyon Teorileri. İstanbul: Küre Yayınları .

Şimşek, M. E. (2016). Modernite, Postmodernite ve Bauman . İstanbul: Belge .

Tanpınar, A. H. (2008). Saatleri Ayarlama Enstitüsü . İstanbul: Dergah.

Toffler, A. (2008). Üçüncü Dalga. (S. Yeniçeri, Çev.) İstanbul: Koridor.

Turkle, S. (1997). Life On the Screen. New York: Touchstone.

Turkle, S. (2005). The Second Self "Computers and the Human Spirit". London: The MIT Press.

Turkle, S. (2008). Always-On/Always-On-You: The Tethered Self. J. E. Katz (Dü.) içinde, Handbook of Mobile Communication Studies. Massachusetts: The MIT Press.

Turkle, S. (2011). Alone Together. New York: Basic Books.

Uzun, K., \& Aydın, C. (2012). Kullanıcı Profilinin ve Bireylerarası İlişkilerin Gerçek Yaşamla

Karşılaştırılması "Second Life Örneği". Eskişehir Osmangazi Üniversitesi İ̈BF Dergisi , 263-290.

Virilio, P. (1991). The Lost Dimension. (D. Moshenberg, Çev.) New York: Semiotext(e). 
AJIT-e: Online Academic Journal of Information Technology

2019 Bahar/Spring-Cilt/Vol: 10 - Sayı/Num: 37

DOI: 10.5824/1309-1581.2019.2.001.x

http://www.ajit-e.org/?menu=pages\&p=details_of_article\&id=421 